\title{
Synthesis, structural characterization and antimycobacterial evaluation of several halogenated non-nitro benzothiazinones
}

\author{
Balungile Madikizela $\mathbb{D}^{1,2} \cdot$ Tamira Eckhardt ${ }^{1} \cdot$ Richard Goddard $\mathbb{D}^{3} \cdot$ Adrian Richter $\mathbb{B}^{1,4} \cdot$ Anika Lins $^{1} \cdot$ \\ Christoph Lehmann ${ }^{1} \cdot$ Peter Imming $\mathbb{1}^{1}$ - Rüdiger W. Seidel $\mathbb{B}^{1}$
}

Received: 31 March 2021 / Accepted: 28 April 2021 / Published online: 10 June 2021

(c) The Author(s) 2021

\begin{abstract}
8-Nitro-1,3-benzothiazin-4-ones (BTZs), with BTZ043 and PBTZ169 as the most advanced compounds, represent a new class of potent antitubercular agents, which irreversibly inhibit decaprenylphosphoryl- $\beta$-D-ribose-2'-epimerase (DprE1), an enzyme crucial for cell wall synthesis in the pathogen Mycobacterium tuberculosis. Synthesis, structural characterization and in vitro testing against Mycobacterium aurum DSM 43999 and M. tuberculosis $\mathrm{H}_{37} \mathrm{Rv}$ of halogenated 2-(4-ethoxycarbonylpiperazin-1-yl)-1,3-benzothiazin-4-ones lacking a nitro group are reported. X-ray crystallography reveals that the structure of the BTZ scaffold can significantly deviate from planarity. In contrast to recent reports, the results of the present study indicate that further investigation of halogenated non-nitro BTZs for antitubercular activity is less than a promising approach.
\end{abstract}

Keywords Benzothiazinones $\cdot$ Tuberculosis $\cdot$ Antimycobacterial evaluation $\cdot$ in vitro activity $\cdot$ Synthesis $\cdot$ Crystal structure

\section{Introduction}

Tuberculosis (TB) is an infectious disease, which is among the top ten causes of death worldwide. An estimated 1.2 million HIV-negative and 208,000 HIV-positive patients died of TB in 2019 [1]. TB is caused by Mycobacterium tuberculosis and typically manifests in the lungs (pulmonary $\mathrm{TB}$ ) but can also affect other organs (extrapulmonary

Supplementary information The online version contains supplementary material available at https://doi.org/10.1007/s00044021-02735-4.

Rüdiger W. Seidel

ruediger.seidel@pharmazie.uni-halle.de

1 Institut für Pharmazie, Martin-Luther-Universität HalleWittenberg, Wolfgang-Langenbeck-Str. 4, Halle (Saale) 06120, Germany

2 Phytomedicine Programme, Department of Paraclinical Sciences, University of Pretoria, Private Bag X04, Onderstepoort 0110, South Africa

3 Max-Planck-Institut für Kohlenforschung, Kaiser-Wilhelm-Platz 1, Mülheim an der Ruhr 45470, Germany

4 Department of Medicine and Department of Microbiology and Immunology, University of British Columbia, Vancouver, BC V6T 1Z3, Canada
TB). Although about $85 \%$ of patients with TB can be cured with a drug regimen of 6 months [1], drug-resistant TB has become a threat to public health [2-4]. Moreover, disruptions of routine services for the management of TB due to lockdowns against SARS-CoV2 may cause a long-lasting increase in TB burdens in certain regions [5]. Novel anti-TB drugs are therefore needed to improve cure rates and to decrease the duration of TB treatments.

Both progression of late stage anti-TB drug candidates into the clinics and early drug discovery are vital to maintain a TB drug pipeline [6]. 1,3-Benzothiazin-4-ones (BTZs) are a promising class of new anti-TB drug candidates, which were first reported by Makarov et al. [7]. The as yet most advanced compounds BTZ043 and PBTZ169 (Scheme 1) exhibit nanomolar in vitro activity against M. tuberculosis and have reached clinical trials [6, 8]. It has been shown that 8-nitro-BTZs are suicide inhibitors of decaprenylphosphoryl- $\beta$-D-ribose $2^{\prime}$-epimerase (DprE1) [9], a mycobacterial enzyme that is crucial for cell wall synthesis and a known drug target $[10,11]$. The drawbacks of nitro-aromatic anti-infective agents [12] such as BTZ043 and PBTZ169 are potential hepatotoxicity [13] and mutagenicity $[14,15]$. Thus, efforts have been made to develop antitubercular BTZs in which the nitro group at C-8 of the BTZ scaffold has been replaced by e.g. a pyrrole [16], an azide [17] or a cyano group [18-20]. 
Scheme 1 Chemical diagrams of BTZ043 and PBTZ169 (macozinone)<smiles>CC1COC2(CCN(c3nc(=O)c4cc(C(F)(F)F)cc([N+](=O)[O-])c4s3)CC2)O1</smiles>

BTZ043<smiles>O=c1nc(N2CCN(CC3CCCCC3)CC2)sc2c([N+](=O)[O-])cc(C(F)(F)F)cc12</smiles>

PBTZ169<smiles>[R]c1c([R])c([R7])c(C(=O)O)c(F)c1[R]</smiles>

1

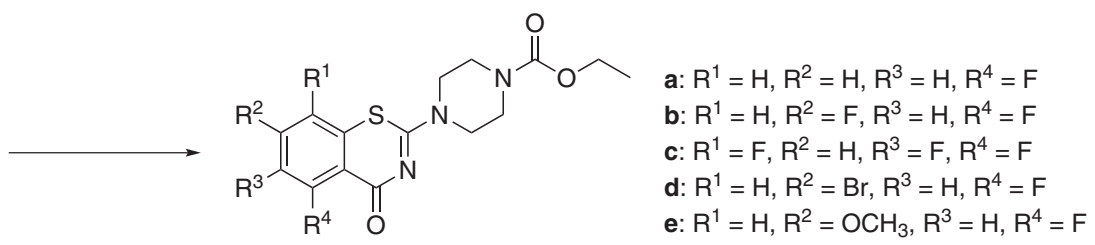

2

Scheme 2 Synthesis of halogenated benzothiazinones $2 \mathbf{2}-\mathbf{e}$

Recently, Nosova et al. published a series of fluorinated BTZs lacking a nitro group, for one of which, namely 5-fluoro2-(4-ethoxycarbonylpiperazine-1-yl)-1,3-benzothiazin-4-one, a promising in vitro activity against $M$. tuberculosis $\mathrm{H}_{37} \mathrm{Rv}$ of $0.7 \mu \mathrm{g} \mathrm{mL}{ }^{-1}(2 \mu \mathrm{M})$ was reported $[21,22]$. Motivated by these findings, we synthesized and structurally characterized the aforementioned most active compound described by Nosova et al. and four related halogenated non-nitro BTZs and tested their in vitro activities against Mycobacterium aurum DSM 43999 and M. tuberculosis $\mathrm{H}_{37} \mathrm{Rv}$. M. aurum, a fast-growing mycobacterial species with low pathogenicity [23], is considered a good model for M. tuberculosis [24, 25]. Herein, we discuss the molecular structures and results of antimycobacterial evaluation of five halogenated non-nitro BTZs.

\section{Results and discussion}

\section{Synthesis}

A variety of methods for the synthesis of BTZs have been described in the literature [26]. The halogenated non-nitro BTZs studied in this work were synthesized from orthofluorobenzoic acids (1) as starting materials (Scheme 2), in analogy to the previously reported synthesis of $\mathbf{2 a}[21,22]$.
The synthesis essentially followed Makarov's original route to BTZs [27]. Treatment of $\mathbf{1}$ with thionyl chloride in toluene afforded the corresponding substituted benzoyl chlorides, which were reacted with ammonium thiocyanate in acetonitrile to yield the halogenated benzoyl isothiocyanates. Reaction with ethyl piperazine-1-carboxylate in acetonitrile gives the corresponding substituted thiourea intermediate products, which in general can be isolated in good yields [22]. In the work described here, the respective isothiocyanate and ethyl piperazine-1-carboxylate were treated in situ with triethylamine to obtain the halogenated BTZs 2 directly through an intramolecular heterocyclization reaction in a one-pot synthesis. Compounds 2a-e were characterized by ${ }^{1} \mathrm{H}$ and ${ }^{13} \mathrm{C}$ NMR spectroscopy and highresolution mass spectrometry (see Supplementary Material).

\section{Structural characterization}

The molecular structures of 2a-e were revealed by X-ray crystallography. 2a $\cdot \mathrm{H}_{2} \mathrm{O}, \mathbf{2 d}$ and $\mathbf{2 e}$ crystallize with one BTZ molecule in the asymmetric unit $\left(Z^{\prime}=1\right)$. Figure 1 depicts the molecular structures. It should be noted that the space groups of these crystal structures are all centrosymmetric and thus the crystals contain the enantiomeric conformers of the molecular structures shown in Fig. 1. 


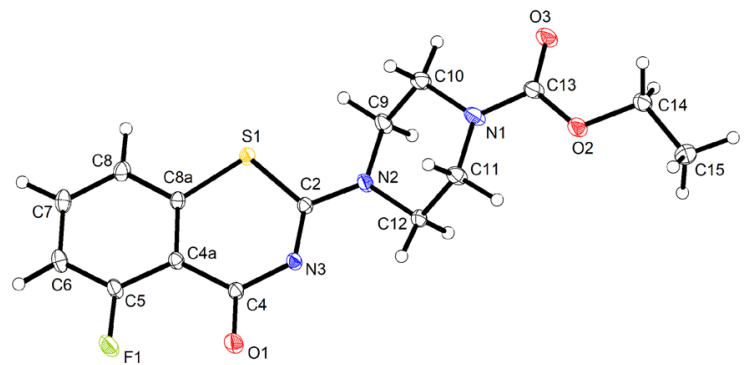

$2 a$

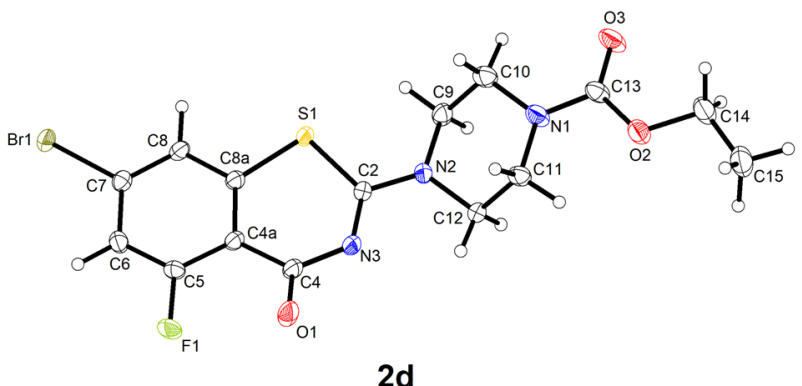

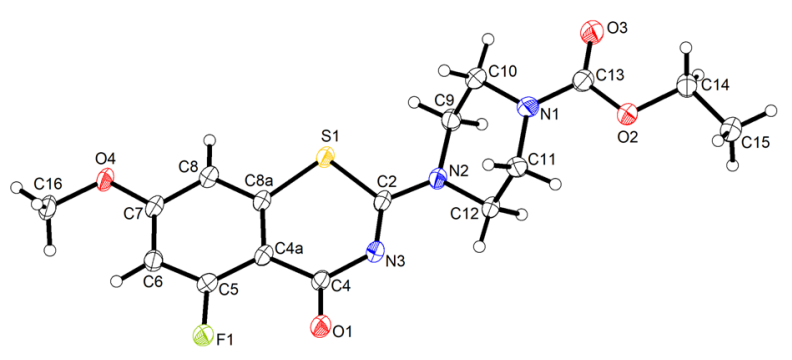

$2 \mathrm{e}$

Fig. 1 Molecular structures of $\mathbf{2 a}, \mathbf{2 d}$ and $\mathbf{2 e}$ in the crystal. Displacement ellipsoids are drawn at the $50 \%$ probability level. Hydrogen atoms are represented by small spheres of arbitrary radius. The solvate water molecule in $\mathbf{2 a} \cdot \mathrm{H}_{2} \mathrm{O}$ is omitted for clarity

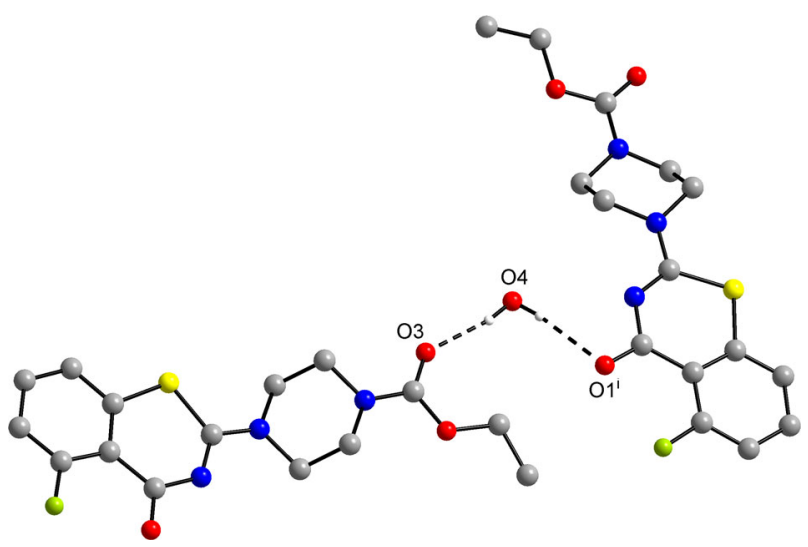

Fig. 2 Hydrogen-bonded association between the solvate water molecule and two molecules of $\mathbf{2 a}$ in the crystal structure of $\mathbf{2 a} \cdot \mathrm{H}_{2} \mathrm{O}$. Carbon-bound hydrogen atoms are omitted for clarity. $d(\mathrm{O} 4 \cdots \mathrm{O} 3)=$ 2.8472(9) $\AA,<(\mathrm{O} 4-\mathrm{H} 4 \mathrm{~A} \cdots \mathrm{O} 3)=169(1)^{\circ} ; d\left(\mathrm{O} 4 \cdots \mathrm{O} 1^{\mathrm{i}}\right)=3.001(1) \AA$, $<\left(\mathrm{O} 4-\mathrm{H} 4 \mathrm{~B} \cdots \mathrm{O} 1^{\mathrm{i}}\right)=172(1)^{\circ}$. Symmetry code: $(\mathrm{i})-\mathrm{x}+1, \mathrm{y}+1 / 2,-\mathrm{z}$ $+3 / 2$

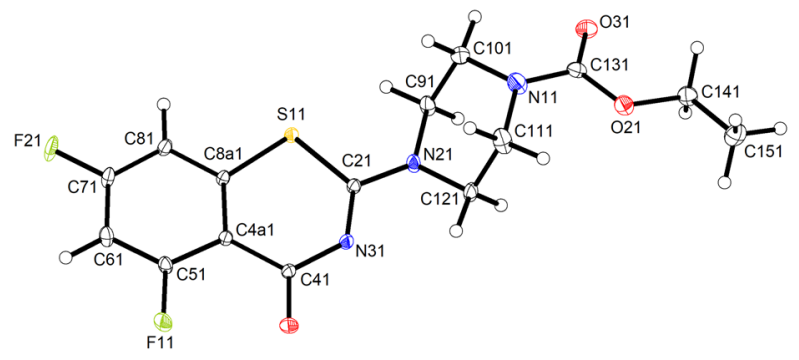

molecule 1

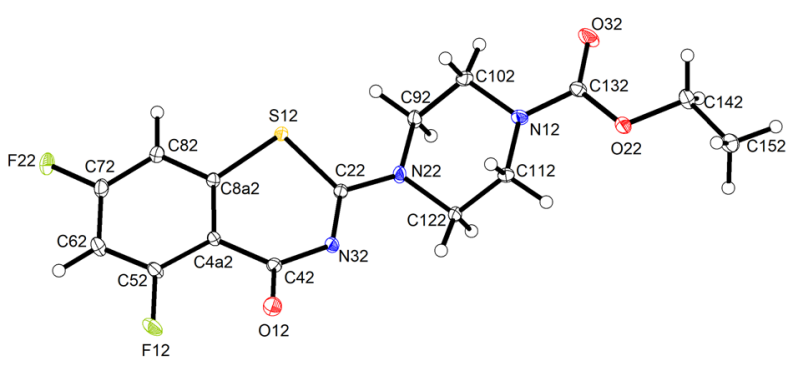

molecule 2

Fig. 3 Displacement ellipsoid plots (50\% probability level) of the two crystallographically unique molecules in $\mathbf{2 b}$. Hydrogen atoms are represented by small spheres of arbitrary radius

In 2a $\cdot \mathrm{H}_{2} \mathrm{O}$ and $\mathbf{2 e}$, the BTZ scaffold is virtually planar, whereas the 1,3-thiazin-4-one moiety deviates significantly from planarity in $\mathbf{2 d}$. $\mathrm{O} 1$ in $\mathbf{2 d}$ is displaced from the mean plane through the condensed benzene ring by $0.515(3) \AA$. The piperazine six-membered ring adopts a low-energy chair conformation in the three structures. The structure at the piperazine nitrogen atoms $\mathrm{N} 1$ and $\mathrm{N} 2$ is virtually planar in each case, which can be ascribed to conjugation of the nitrogen lone pair with the carboxylate group and the BTZ $\pi$ electron system, respectively. The carbamate group is virtually planar, as expected, and the ethyl group adopts an anti conformation about the $\mathrm{O} 2-\mathrm{C} 14$ bond. In $2 \mathbf{e}$, the methoxy group lies almost in the benzene ring plane, as expected [28], with a $\mathrm{C} 6-\mathrm{C} 7-\mathrm{O} 4-\mathrm{C} 16$ torsion angle of 2.1(3) ${ }^{\circ}$. The water molecule in $\mathbf{2 a} \cdot \mathrm{H}_{2} \mathrm{O}$ acts as a hydrogen donor towards the carbonyl oxygen atom $\mathrm{O} 3$ of the carbamate group and $\mathrm{O} 1$ of the BTZ scaffold of an adjacent molecule (Fig. 2). Geometric parameters of the hydrogen bonds lie within the expected range for $\mathrm{O}-\mathrm{H} \cdots \mathrm{O}=\mathrm{C}$ hydrogen bonds [29]. Aside from the hydrogen-bonded water molecule in $\mathbf{2 a} \cdot \mathrm{H}_{2} \mathrm{O}$, the crystal structures appear to be governed by close packing. The packing index is $72.1 \%$ for $\mathbf{2 a} \cdot \mathrm{H}_{2} \mathrm{O}, 70.5 \%$ for $\mathbf{2 d}$ and $72.2 \%$ for $\mathbf{2 e}$, indicating a dense crystal packing [30]. Short interhalogen contacts are not encountered.

In contrast to $\mathbf{2 a} \cdot \mathrm{H}_{2} \mathrm{O}, \mathbf{2 d}$ and $\mathbf{2 e}, \mathbf{2 b}$ with fluorine substituents in the 5 and 7 positions of the BTZ scaffold crystallizes with two molecules in the asymmetric unit 


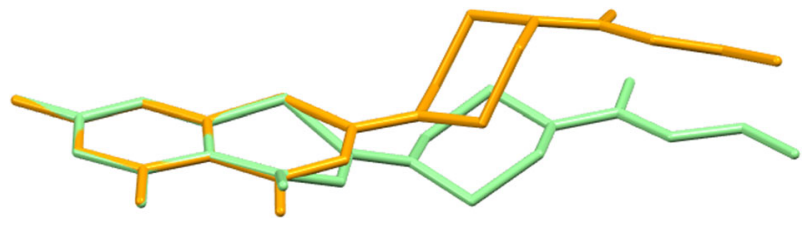

Fig. 4 Structure overlay diagram of the benzene rings of the crystallographically unique molecules 1 (orange) and 2 (green) in $\mathbf{2 b}$. Hydrogen atoms are omitted for clarity
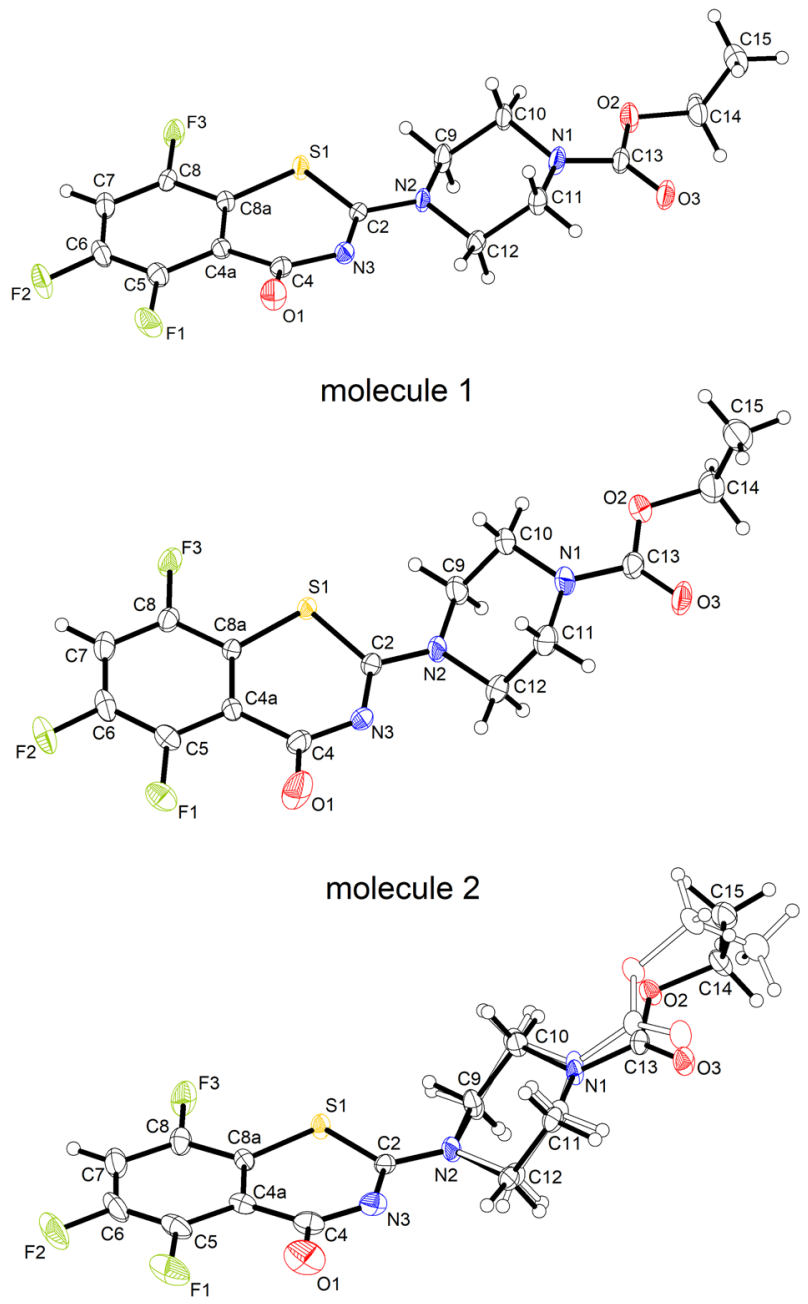

molecule 3

Fig. 5 Displacement ellipsoid plots (50\% probability level) of the three crystallographically unique molecules in 2c. Hydrogen atoms are represented by small spheres of arbitrary radius. The minor disorder part (49\%) in molecule 3 is shown by empty ellipsoids

$\left(Z^{\prime}=2\right)$ [31]. Figure 3 depicts the two crystallographically unique molecules. Since the crystal structure is centrosymmetric, the enantiomeric conformers of both molecules are also present in the unit cell. In molecule 1, the BTZ scaffold is virtually planar as for $\mathbf{2 a} \cdot \mathrm{H}_{2} \mathrm{O}$ and $\mathbf{2 e}$. In molecule 2, however, the 1,3-thiazin-4-one six-membered

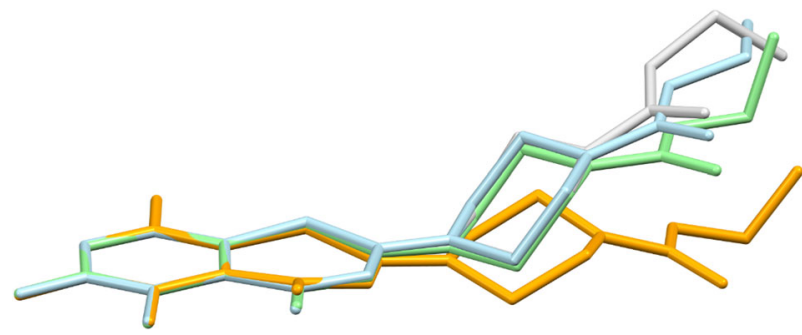

Fig. 6 Structure overlay diagram of the benzene rings of the crystallographically unique molecules 1 (orange), 2 (green) and 3 (blue for the major and grey for the minor disorder component) in 2c. Hydrogen atoms are omitted for clarity

ring adopts a significant boat form with $\mathrm{C} 22$ and $\mathrm{N} 32$ located 0.46(2) and 0.41(2) $\AA$, respectively, above the mean plane through the condensed benzene ring, and $\mathrm{O} 12$ lying $0.38(1) \AA$ below this plane. A structure overlay diagram, shown in Fig. 4, illustrates the structural differences between the two crystallographically unique molecules. The ethyl piperazine-1-carboxylate moiety adopts the same conformation as in $\mathbf{2 a} \cdot \mathrm{H}_{2} \mathrm{O}, \mathbf{2} \mathbf{d}$ and $\mathbf{2 e}$, as described above. In the crystal, the molecules are densely packed with a packing index of $72.3 \%$.

Compound $2 \mathbf{c}$ crystallizes with three molecules in the asymmetric unit $\left(Z^{\prime}=3\right)$ [31]. This crystal phase (space group $C c$ ) was encountered at $100 \mathrm{~K}, 150 \mathrm{~K}$ and room temperature. Figure 5 depicts the structures of the three crystallographically unique molecules. With regard to the space group symmetry, the enantiomeric conformers are also present in the unit cell. Molecule 3 exhibits disorder of the ethyl piperazine-1-carboxylate moiety. In molecule 1, the benzothiazinone scaffold shows significant deviations from planarity with $\mathrm{O} 1$ displaced from the mean plane through the benzene ring by $0.488(6) \AA$. In molecules 2 and 3 the benzothiazinone scaffold is virtually planar. Figure 6 shows a structure overlay plot of the three unique molecules. As in $\mathbf{2 a} \cdot \mathrm{H}_{2} \mathrm{O}, \mathbf{2} \mathbf{b}, \mathbf{2} \mathbf{d}$ and $\mathbf{2 e}$, the piperazine ring adopts a low-energy chair conformation in the three unique molecules in 2c, but in contrast the ethyl group is tilted out of plane of the carbamate moiety $[\mathrm{C}-\mathrm{O}-\mathrm{C}-\mathrm{C}$ torsion angles: $-88.1(4),-90.5(5)$ and $-85.3(8)^{\circ}$, with exception of the minor disorder component of molecule 3 where the $\mathrm{C}-\mathrm{O}-\mathrm{C}-\mathrm{C}$ torsion angle is $173.0(7)^{\circ}$. Intermolecular short F...F contacts, with respect to the van der Waals radii [32], are observed between molecule 2 and molecule 3 . It is worth noting that in the solid of $\mathbf{2 c}$ there are short $\mathrm{N}-\mathrm{C}-\mathrm{H} \cdots \mathrm{O}=\mathrm{C}$ intermolecular contacts $(D \cdots A$ distances < $3.3 \AA$ ) between the methylene groups of the piperazine moieties and carbonyl oxygen atoms of both the benzothiazone and the ester parts of all independent molecules, with the exception of the disordered ester in molecule, indicating that these contacts may be the result of an attractive $\mathrm{N}-\mathrm{C}-\mathrm{H} \cdots \mathrm{O}=\mathrm{C}$ interaction. 
Structural information on BTZs is still limited in the literature. Structures of the nitroso forms of BTZ043 (PDB code: 4F4Q) [33], related BTZs [34] and PBTZ169 (4NCR) [35] covalently bound to DprE1 can be found in the Protein Data Bank (PDB) [36]. In the crystal structure of the M. tuberculosis DprE1-PBTZ169 complex (4NCR; resolution: $1.9 \AA$ ), the covalently bound nitroso form of the piperazinyl-BTZ PBTZ169 (Scheme 1) exhibits a virtually planar BTZ scaffold, and the piperazine ring adopts chair conformation, similar to the structures of 2a-e. A water molecule bridges the BTZ carbonyl oxygen atom and the backbone carbonyl oxygen atom of a leucine moiety via hydrogen bonding in $4 \mathrm{NCR}$, which has some similarity to the hydrogen-bonding pattern in the crystal structure of $\mathbf{2 a}$. $\mathrm{H}_{2} \mathrm{O}$ (Fig. 2). In March 2021, only four small molecule structures of BTZs were available in the Cambridge Structural Database (CSD) [37], as revealed by a WebCSD search [38]. The crystal structure of PBTZ169 (CSD refcode: LOPXAS) was reported by Zhang and Aldrich [39] and that of its 8-CN analogue (WALHAW) very recently by Zhang et al. [18]. A virtually planar BTZ scaffold and a chair conformation of the piperazine ring are encountered in both structures. This is comparable with the conformations observed in $\mathbf{2 a} \cdot \mathrm{H}_{2} \mathrm{O}$, $\mathbf{2 e}$ and molecule 1 in $\mathbf{2 b}$. To date, the crystal structures of two fluorinated non-nitro BTZs have been reported, namely 6,7,8-trifluoro-2-(thiomorpholin-4yl)-1,3-benzothiazin-4-one (DOGXUV) [22] and 5-fluoro2-(1-methyl-1H-pyrrol-2-yl)-1,3-benzothiazin-4-one (SOJGOQ) [40]. DOGXUV likewise exhibits a planar BTZ scaffold with the tethered thiomorpholin ring in a chair conformation. In SOJGOQ, the 1,3-thiazin-4-one moiety adopts a slight boat shape similar to $\mathbf{2 d}$ and molecule 2 in $\mathbf{2 b}$ but with the sulfur atom disordered over two positions. In contrast to $\mathbf{2 a} \cdot \mathrm{H}_{2} \mathrm{O}, \mathbf{2 b}, \mathbf{2 d}, \mathbf{2 e}$ and SOJGOQ, intermolecular F...F contacts that are closer than the sum of the van der Waals radii [32] are found in DOGXUV, which may be classified as type I C-F...F-C interactions [41].

\section{Antimycobacterial evaluation}

The antimycobacterial activity of halogenated non-nitro BTZs 2a-e was tested in vitro against $M$. tuberculosis $\mathrm{H}_{37} \mathrm{Rv}$ and M. aurum DSM 43999 (Table 1). BTZ043 was included as a reference compound, and the observed $\mathrm{MIC}_{90}$ value against $M$. tuberculosis $\mathrm{H}_{37} \mathrm{Rv}$ is consistent with the literature [7, 33]. Against M. tuberculosis $\mathrm{H}_{37} \mathrm{Rv}, 2 d$ inhibited growth at a concentration of $60 \mu \mathrm{M}$, whereas the other non-nitro BTZs studied did not show any antimycobacterial effect at the concentrations tested. In contrast to our results, Nosova et al. reported a MIC of $0.7 \mu \mathrm{g} \mathrm{mL}$ $(2 \mu \mathrm{M})$ for $\mathbf{2 a}$ against $M$. tuberculosis $\mathrm{H}_{37} \mathrm{Rv}[21,22]$. We assume that major differences in the assay protocols used are responsible for this observation. Nosova et al. cultured
Table 1 In vitro antimycobacterial activity of halogenated non-nitro BTZs 2a-e and the reference compound BTZ043

\begin{tabular}{lll}
\hline Compound & $\begin{array}{l}\text { M. tuberculosis } \mathrm{H}_{37} \mathrm{Rv} \\
\mathrm{MIC}_{90} / \mu \mathrm{M}\end{array}$ & $\begin{array}{l}\text { M. aurum DSM } 43999 \\
\mathrm{MIC} / \mu \mathrm{M}\end{array}$ \\
\hline 2a & $>30$ & $>100$ \\
2b & $>100$ & $>100$ \\
2c & $>100$ & 36 \\
2d & 60 & 48 \\
2e & $>100$ & 71 \\
BTZ043 & 0.003 & 0.008 \\
\hline
\end{tabular}

M. tuberculosis $\mathrm{H}_{37} \mathrm{Rv}$ in Löwenstein-Jensen medium and evaluated the antimycobacterial effect of the test compounds by measuring the zone of growth retardation in test tubes, whereas our assay was carried out in 7H9 medium supplemented with $10 \%$ OADC and $0.05 \%$ polysorbate 80 using 96-well plates. For the assay system used in the present study, a M. tuberculosis $\mathrm{H}_{37} \mathrm{Rv}$ strain transformed with the pTEC27 plasmid [42, 43] for RFP expression was used and growth was analyzed after 7 days of incubation by fluorescence measurement [44, 45]. For MIC determination against M. aurum DSM 43999, a broth microdilution method with iodonitrotetrazolium chloride (INT) as indicator reagent was used. $\mathbf{2 c}, \mathbf{2 d}$ and $2 \mathbf{e}$ showed modest activity with MICs between 36 and $71 \mu \mathrm{M}$ against $M$. aurum DSM 43999, whereas 2a and 2b do not exhibit activity against this mycobacterial strain.

In summary, antimycobacterial evaluation of 2a-e did not reveal potent effects in vitro. Compared with 8-nitro-BTZs with nanomolar in vitro activity against $M$. tuberculosis [7, 46], the halogenated non-nitro congeners studied in the present work clearly display loss of activity. The presence of a nitro group at C-8 of the BTZ scaffold seems to be essential for the efficient, mechanism-based inhibition of DprE1 with high in vitro potency. Our findings thus are in line with previous studies that showed that 8-nitro BTZs bind covalently to DprE1 through linkage of their nitroso forms to the Cys387 residue in the FAD-binding domain [9, 33, 34, 47, 48]. It should be noted, however, that BTZs where the 8-nitro group was replaced by a pyrrole ring, and which are thought to act as non-covalent DprE1 inhibitors, showed similar in vitro activity but no efficacy in animal models [16].

\section{Conclusions}

We synthesized and structurally characterized halogenated BTZs 2a-e lacking a nitro group at C-8 of the BTZ scaffold, and investigated their in vitro activities against $M$. aurum DSM 43999 and M. tuberculosis $\mathrm{H}_{37} \mathrm{Rv}$. Structural characterization by X-ray crystallography revealed that the crystal packing can cause significant deviations from planarity in the 
BTZ moiety. The orientation of the ethyl piperazine-1carboxylate moiety with respect to the BTZ plane gives rise to two enantiomeric conformers in the solid state in every case. The crystal structure of $\mathbf{2 a} \cdot \mathrm{H}_{2} \mathrm{O}$ furthermore gives structural insight into hydrogen bonding acceptor properties of the BTZ molecule. In the absence of water of crystallization, the methylene groups of the piperazine ring appear to act as weak hydrogen bond donors to BTZ and carbamate carbonyl oxygen atoms. In vitro tests against $M$. aurum and M. tuberculosis did not reveal potent inhibitory effects, which lends support to the view that the 8-nitro group is essential for an efficient, mechanism-based inhibition of DprE1. In contrast to recent reports literature, our results thus indicate that further investigation of halogenated non-nitro BTZs for antitubercular activity is less than a promising approach.

\section{Experimental}

\section{General}

Starting materials were purchased and used as received. Solvents were distilled prior to use and stored over $4 \AA$ molecular sieves. Column chromatography was carried out using Merck silica gel $60(63-200 \mu \mathrm{m})$. Flash chromatography was performed on a puriFlash ${ }^{\oplus} 430$ instrument (Interchim, Montluçon, France). Prepacked columns with silica gel $(30 \mu \mathrm{m})$ were used. The maximum compound load per column was $5 \%(\mathrm{~m} / \mathrm{m})$ of the silica gel quantity. The synthesis of BTZ043 is described elsewhere [27]. Melting points (uncorrected) were determined on a Boëtius hot-stage apparatus (VEB Kombinat, NAGEMA, Dresden, GDR). NMR spectra were recorded on an Agilent Technologies VNMRS $400 \mathrm{MHz}$ and a Varian INOVA 500 NMR spectrometer. Chemical shifts are reported relative to the residual solvent signal (chloroform- $d$ : $\delta_{\mathrm{H}}=7.26 \mathrm{ppm}, \delta_{\mathrm{C}}=$ $77.16 \mathrm{ppm}$; methanol- $d_{4}: \delta_{\mathrm{H}}=3.31 \mathrm{ppm}, \delta_{\mathrm{C}}=49.00 \mathrm{ppm}$; DMSO- $\left.d 6 \delta_{\mathrm{H}}=2.50 \mathrm{ppm}, \delta_{\mathrm{C}}=39.52 \mathrm{ppm}\right)$. Abbreviations: $\mathrm{s}=$ singlet, $\mathrm{bs}=$ broad singlet, $\mathrm{d}=$ doublet, $\mathrm{dd}=$ doublet of doublets, $\mathrm{m}=$ multiplet. ESI high-resolution mass spectra (HRMS) were recorded on a Thermo Fisher Scientific LTQ Orbitrap XL mass spectrometer for $\mathbf{2 b}, \mathbf{2 c}$ and $\mathbf{2 e}$, and on a Thermo Scientific Q Exactive ${ }^{\mathrm{TM}}$ Plus Orbitrap mass spectrometer for $\mathbf{2 a}$ and $\mathbf{2 d}$.

\section{Synthesis}

\section{General method for the preparation of the substituted benzoyl chloride precursors}

The respective substituted benzoic acid was dissolved in toluene (ca. $20 \mathrm{~mL}$ per mmol) and two equivalents of thionyl chloride were added. After heating to reflux for $2 \mathrm{~h}$, the solvent and excess thionyl chloride were removed in vacuum and the substituted benzoyl chloride thus obtained was used in the next synthetic step without purification.

\section{5-Fluoro-2-(4-ethoxycarbonylpiperazine-1-yl)-1,3- benzothiazin-4-one (2a)}

The synthesis of $\mathbf{2 a}$ can be found in the literature [22]. ${ }^{1} \mathrm{H}$ NMR (400 MHz, DMSO- $\left.d_{6}\right) \delta 7.65(\mathrm{td}, J=8.1,5.0 \mathrm{~Hz}, 1 \mathrm{H}$, aromatic $\mathrm{CH}), 7.46(\mathrm{~d}, J=8.0 \mathrm{~Hz}, 1 \mathrm{H}$, aromatic $\mathrm{CH}), 7.29$ (ddd, $J=11.2,8.2,0.9 \mathrm{~Hz}, 1 \mathrm{H}$, aromatic $\mathrm{CH}), 4.08(\mathrm{q}, J=$ $7.1 \mathrm{~Hz}, 2 \mathrm{H}$, ethyl $\left.\mathrm{CH}_{2}\right), 3.93-3.67(\mathrm{~m}, 4 \mathrm{H}$, piperazinyl $\left.\mathrm{CH}_{2}\right), 3.59-3.46\left(\mathrm{~m}, 4 \mathrm{H}\right.$, piperazinyl $\left.\mathrm{CH}_{2}\right), 1.21(\mathrm{t}, J=$ $7.1 \mathrm{~Hz}, 3 \mathrm{H}$, ethyl $\left.\mathrm{CH}_{3}\right) .{ }^{13} \mathrm{C}$ NMR $\left(126 \mathrm{MHz}, \mathrm{DMSO}-d_{6}\right) \delta$ $165.0\left(\mathrm{~d}, J_{\mathrm{C}, \mathrm{F}}=5.1 \mathrm{~Hz}\right), 161.8\left(\mathrm{~d}, J_{\mathrm{C}, \mathrm{F}}=262 \mathrm{~Hz}\right), 160.2$, $154.5,134.4,133.6\left(\mathrm{~d}, J_{\mathrm{C}, \mathrm{F}}=10 \mathrm{~Hz}\right), 122.3\left(\mathrm{~d}, J_{\mathrm{C}, \mathrm{F}}=\right.$ $4 \mathrm{~Hz}), 116.3\left(\mathrm{~d}, J_{\mathrm{C}, \mathrm{F}}=23 \mathrm{~Hz}\right), 112.4\left(\mathrm{~d}, J_{\mathrm{C}, \mathrm{F}}=9 \mathrm{~Hz}\right), 61.0$, 45.2, 42.6, 14.5 ppm. $m / z \quad[\mathrm{M}+\mathrm{Na}]^{+}$calcd. for $\mathrm{C}_{15} \mathrm{H}_{16} \mathrm{FN}_{3} \mathrm{NaO}_{3} \mathrm{~S}^{+}$360.07886, found 360.07878 .

\section{5,7-Difluoro-2-(4-ethoxycarbonylpiperazine-1-yl)-1,3- benzothiazin-4-one (2b)}

2,4,6-Trifluorobenzoyl chloride $(5.14 \mathrm{mmol})$ was prepared by the general method and taken up in $2 \mathrm{~mL}$ of acetonitrile and a solution of ammonium thiocyanate $(0.39 \mathrm{~g}, 5.14 \mathrm{mmol})$ in $15 \mathrm{~mL}$ of acetonitrile was added with stirring. The reaction mixture was stirred for $5 \mathrm{~min}$ at $40^{\circ} \mathrm{C}$ and the ammonium chloride precipitate so formed was removed by filtration and ethyl piperazine-1-carboxylate $(0.75 \mathrm{~mL}, 5.14 \mathrm{mmol})$ was added with stirring. After stirring for $3 \mathrm{~h}$ at room temperature, triethylamine $(1.4 \mathrm{~mL}, 10.28 \mathrm{mmol})$ was added dropwise and the mixture was stirred overnight. Subsequently, the solvent was removed under reduced pressure and the crude product was purified by flash chromatography (ethyl acetate/heptane gradient). It was obtained as an off-white solid; mp 152-157 ${ }^{\circ} \mathrm{C}$; yield: $0.56 \mathrm{mg}$ (1.58 mmol, $\left.31 \%\right) .{ }^{1} \mathrm{H}$ NMR $\left(400 \mathrm{MHz}, \mathrm{MeOH}-d_{4}\right) \delta 7.28$ (ddd, $J=8.3,2.5 \mathrm{~Hz}, 1.5 \mathrm{~Hz}$, $1 \mathrm{H}$, aromatic $\mathrm{CH}), 7.13$ (ddd, $J=11.3,9.0,2.5 \mathrm{~Hz}, 1 \mathrm{H}$, aromatic $\mathrm{CH}$ ), 4.17 (q, $J=7.1 \mathrm{~Hz}, 2 \mathrm{H}$, ethyl $\left.\mathrm{CH}_{2}\right), 4.06-3.74(\mathrm{~m}$, $4 \mathrm{H}$, piperazinyl $\left.\mathrm{CH}_{2}\right), 3.71-3.56\left(\mathrm{~m}, 4 \mathrm{H}\right.$, piperazinyl $\left.\mathrm{CH}_{2}\right)$, $1.28\left(\mathrm{t}, J=7.1 \mathrm{~Hz}, 3 \mathrm{H}\right.$, ethyl $\left.\mathrm{CH}_{3}\right) \mathrm{ppm} .{ }^{13} \mathrm{C} \mathrm{NMR}(101 \mathrm{MHz}$, $\left.\mathrm{MeOH}-d_{4}\right) \delta 168.3\left(\mathrm{~d}, J_{\mathrm{C}, \mathrm{F}}=5 \mathrm{~Hz}\right), 167.0-166.6(\mathrm{~m}), 164.1$ $\left(\mathrm{dd}, J_{\mathrm{C}, \mathrm{F}}=23,13 \mathrm{~Hz}\right), 162.9,157.0,139.0\left(\mathrm{dd}, J_{\mathrm{C}, \mathrm{F}}=12 \mathrm{~Hz}\right.$, $2 \mathrm{~Hz}), 110.2\left(\mathrm{dd}, J_{\mathrm{C}, \mathrm{F}}=26 \mathrm{~Hz}\right), 110.2-110.1(\mathrm{~m}), 106.4(\mathrm{dd}$, $\left.J_{\mathrm{C}, \mathrm{F}}=27,26 \mathrm{~Hz}\right), 63.1,46.9,44.0,14.9 \mathrm{ppm} . \mathrm{HRMS}\left(\mathrm{ESI}^{+}\right)$: $m / z \quad[\mathrm{M}+\mathrm{Na}]^{+}$calcd. for $\mathrm{C}_{15} \mathrm{H}_{15} \mathrm{~F}_{2} \mathrm{~N}_{3} \mathrm{NaO}_{3} \mathrm{~S}^{+}$378.0695, found 378.0692 .

\section{5,6,8-Trifluoro-2-(4-ethoxycarbonylpiperazine-1-yl)-1,3- benzothiazin-4-one $(2 c)$}

Compound $\mathbf{2 c}$ was synthesized analogously to $\mathbf{2 b}$ from 2,3,5,6-tetrafluorobenzoyl chloride $(4.71 \mathrm{mmol})$. In addition 
to the target compound $\mathbf{2 c}$, the thiourea intermediate product (see Scheme 2) was isolated by flash chromatography. It was taken up with $5 \mathrm{~mL}$ of dimethylformamide and treated with $2.3 \mathrm{~mL}$ of triethylamine. After stirring overnight and heating to $70{ }^{\circ} \mathrm{C}$ for $2 \mathrm{~h}$, additional $2 \mathrm{c}$ was isolated after removal of the solvent and recrystallization from isopropanol. It was obtained as an off-white solid; mp $192-197^{\circ} \mathrm{C}$; yield: $0.62 \mathrm{~g}$ $(1.66 \mathrm{mmol}, 35 \%) .{ }^{1} \mathrm{H}$ NMR $(500 \mathrm{MHz}$, chloroform- $d) \delta$ $7.22(\mathrm{td}, J=9.1,5.9 \mathrm{~Hz}, 1 \mathrm{H}$, aromatic $\mathrm{CH}), 4.18(\mathrm{q}, J=$ $7.1 \mathrm{~Hz}, 2 \mathrm{H}$, ethyl $\mathrm{CH}_{2}$ ), 3.89 (bs, $4 \mathrm{H}$, piperazinyl $\mathrm{CH}_{2}$ ), 3.64-3.52 (m, 4H, piperazinyl $\left.\mathrm{CH}_{2}\right), 1.28(\mathrm{t}, J=7.1 \mathrm{~Hz}, 3 \mathrm{H}$, ethyl $\left.\mathrm{CH}_{3}\right) .{ }^{13} \mathrm{C}$ NMR $(126 \mathrm{MHz}$, chloroform- $d$ ) $\delta 165.1$, $160.1,155.3,152.0\left(\mathrm{ddd}, J_{\mathrm{C}, \mathrm{F}}=246,10,5 \mathrm{~Hz}\right), 149.7$ (ddd, $\left.J_{\mathrm{C}, \mathrm{F}}=254,15,12 \mathrm{~Hz}\right), 148.1\left(\mathrm{ddd}, J_{\mathrm{C}, \mathrm{F}}=265,14,4 \mathrm{~Hz}\right)$, $116.8\left(\mathrm{dd}, J_{\mathrm{C}, \mathrm{F}}=18,4 \mathrm{~Hz}\right), 114.6\left(\mathrm{dd}, J_{\mathrm{C}, \mathrm{F}}=7,2 \mathrm{~Hz}\right), 108.6$ $\left(\mathrm{dd}, J_{\mathrm{C}, \mathrm{F}}=25,23 \mathrm{~Hz}\right), 62.2,46.1,43.2,14.7 . \mathrm{HRMS}\left(\mathrm{ESI}^{+}\right)$: $\mathrm{m} / \mathrm{z}[\mathrm{M}+\mathrm{H}]^{+}$calcd. for $\mathrm{C}_{15} \mathrm{H}_{15} \mathrm{~F}_{3} \mathrm{~N}_{3} \mathrm{O}_{3} \mathrm{~S}^{+} 374.0781$, found $374.0780, \quad[\mathrm{M}+\mathrm{Na}]^{+}$calcd. for $\mathrm{C}_{15} \mathrm{H}_{14} \mathrm{~F}_{3} \mathrm{O}_{3} \mathrm{~N}_{3} \mathrm{NaS}^{+}$ 396.0601, found 396.0603.

\section{7-Bromo-5-fluoro-2-(4-ethoxycarbonylpiperazine-1-yl)-1,3- benzothiazin-4-one $(2 \mathrm{~d})$}

Compound 2d was synthesized analogously to $\mathbf{2 b}$ from 4bromo-2,6-difluorobenzoyl chloride but heated to reflux overnight. It was obtained as an off-white solid; mp 225-227\% yield: $0.51 \mathrm{~g}(1.23 \mathrm{mmol}, 29 \%) .{ }^{1} \mathrm{H}$ NMR $(400 \mathrm{MHz}$, chloroform- $d$ ) $\delta$ 7.34-7.27 (m, 2H, aromatic $\mathrm{CH}), 4.18\left(\mathrm{q}, J=7.1 \mathrm{~Hz}, 2 \mathrm{H}\right.$, ethyl $\left.\mathrm{CH}_{2}\right), 4.00-3.73(\mathrm{~m}$, $4 \mathrm{H}$, piperazinyl $\left.\mathrm{CH}_{2}\right), 3.66-3.54\left(\mathrm{~m}, 4 \mathrm{H}\right.$, piperazinyl $\left.\mathrm{CH}_{2}\right)$, $1.28\left(\mathrm{t}, J=7.1 \mathrm{~Hz}, 3 \mathrm{H}\right.$, ethyl $\left.\mathrm{CH}_{3}\right) .{ }^{13} \mathrm{C}$ NMR $(126 \mathrm{MHz}$, chloroform- $d) \delta 165.8\left(\mathrm{~d}, J_{\mathrm{C}, \mathrm{F}}=5 \mathrm{~Hz}\right), 162.4\left(\mathrm{~d}, J_{\mathrm{C}, \mathrm{F}}=\right.$ $270.4 \mathrm{~Hz}), 160.0,155.1,136.1,126.1\left(\mathrm{~d}, J_{\mathrm{C}, \mathrm{F}}=11 \mathrm{~Hz}\right)$, $124.1\left(\mathrm{~d}, J_{\mathrm{C}, \mathrm{F}}=5 \mathrm{~Hz}\right), 120.1\left(\mathrm{~d}, J_{\mathrm{C}, \mathrm{F}}=26 \mathrm{~Hz}\right), 62.0,45.8$, 43.1, 14.6. $\mathrm{HRMS}\left(\mathrm{ESI}^{+}\right): \mathrm{m} / z \quad[\mathrm{M}+\mathrm{Na}]^{+}$calcd. for $\mathrm{C}_{15} \mathrm{H}_{15} \mathrm{BrFN}_{3} \mathrm{NaO}_{3} \mathrm{~S}^{+}$: 437.98939, found 437.98965 .

\section{5-Fluoro-7-methoxy-2-(4-ethoxycarbonylpiperazine-1-yl)- 1,3-benzothiazin-4-one (2e)}

Compound $\mathbf{2 e}$ was synthesized analogously to $\mathbf{2 b}$ from 2,6difluoro-4-methoxybenzoyl chloride $(5.32 \mathrm{mmol})$ but heated to reflux overnight. It was obtained as a pale brown solid; mp $218-221{ }^{\circ} \mathrm{C}$; yield: $0.32 \mathrm{~g}(0.87 \mathrm{mmol}, 16 \%) .{ }^{1} \mathrm{H}$ NMR (400 MHz, chloroform- $d$ ) $\delta 6.67(\mathrm{dd}, J=12.2,2.5 \mathrm{~Hz}, 1 \mathrm{H}$, aromatic $\mathrm{CH}), 6.63(\mathrm{dd}, J=2.5,1.1 \mathrm{~Hz}, 1 \mathrm{H}$, aromatic $\mathrm{CH})$, $4.18\left(\mathrm{q}, J=7.1 \mathrm{~Hz}, 2 \mathrm{H}\right.$, ethyl $\left.\mathrm{CH}_{2}\right), 4.03-3.69(\mathrm{~m}, 7 \mathrm{H}$, piperazinyl $\mathrm{CH}_{2}$ and methoxy $\left.\mathrm{CH}_{3}\right), 3.64-3.55(\mathrm{~m}, 4 \mathrm{H}$, piperazinyl $\left.\mathrm{CH}_{2}\right), 1.29\left(\mathrm{t}, J=7.1 \mathrm{~Hz}, 3 \mathrm{H}\right.$, ethyl $\left.\mathrm{CH}_{3}\right) \cdot{ }^{13} \mathrm{C}$ NMR $(101 \mathrm{MHz}$, chloroform- $d) \delta 165.7\left(\mathrm{~d}, J_{\mathrm{C}, \mathrm{F}}=5 \mathrm{~Hz}\right)$, $163.5\left(\mathrm{~d}, J_{\mathrm{C}, \mathrm{F}}=266 \mathrm{~Hz}\right), 161.7\left(\mathrm{~d}, J_{\mathrm{C}, \mathrm{F}}=13 \mathrm{~Hz}\right), 159.5$, 154.4, $135.1\left(\mathrm{~d}, J_{\mathrm{C}, \mathrm{F}}=3 \mathrm{~Hz}\right), 105.5\left(\mathrm{~d}, J_{\mathrm{C}, \mathrm{F}}=4 \mathrm{~Hz}\right), 105.3$ $\left(\mathrm{d}, J_{\mathrm{C}, \mathrm{F}}=10 \mathrm{~Hz}\right), 102.5\left(\mathrm{~d}, J_{\mathrm{C}, \mathrm{F}}=27 \mathrm{~Hz}\right), 61.1,55.1,44.8$,
42.3, 13.8. $\operatorname{HRMS}\left(\mathrm{ESI}^{+}\right): \quad m / z \quad[\mathrm{M}+\mathrm{H}] \quad$ calcd. for $\mathrm{C}_{16} \mathrm{H}_{19} \mathrm{FN}_{3} \mathrm{O}_{4} \mathrm{~S}^{+} 368.1075$, found 368.1079, $[\mathrm{M}+\mathrm{Na}]^{+}$ calcd. for $\mathrm{C}_{16} \mathrm{H}_{18} \mathrm{FN}_{3} \mathrm{NaO}_{4} \mathrm{~S}^{+}$390.0895, found 390.0893.

\section{X-ray crystallography}

Crystals suitable for single-crystal X-ray diffraction were grown from dimethylformamide for $\mathbf{2 a} \cdot \mathrm{H}_{2} \mathrm{O}$, toluene for $\mathbf{2 b}$, acetone for $\mathbf{2 c}$ and methanol for $\mathbf{2 d}$ and $\mathbf{2 e}$. Diffraction data were measured at the P11 beamline at PETRA III at DESY $[49,50]$ with a Pilatus $6 \mathrm{M}$ detector [51] for $\mathbf{2 a} \cdot \mathrm{H}_{2} \mathrm{O}, \mathbf{2 b}$ and 2e, on a Bruker AXS Kappa Mach3 APEXII diffractometer equipped with Incoatec microfocus source for $\mathbf{2 c}$, and on a Bruker AXS Kappa Mach3 APEXII diffractometer equipped with a FR591 $\mathrm{Cu}$ rotating anode X-ray source for $\mathbf{2 d}$. The data were processed with XDS [52] for $\mathbf{2 a} \cdot \mathrm{H}_{2} \mathrm{O}, \mathbf{2 b}$ and $\mathbf{2 e}$ and SAINT [53] for $\mathbf{2 c}$ and $\mathbf{2 d}$. For $\mathbf{2 c}$ and $\mathbf{2 d}$, an absorption correction by face-indexed Gaussian integration was applied with SADABS [54]. The crystal structures were solved with SHELXT [55] and refined with SHELXL-2018/3 [56]. 2a . $\mathrm{H}_{2} \mathrm{O}$, 2b and $2 \mathbf{d}$ were refined using aspherical scattering factors [57], except for the water oxygen atom $\mathrm{O} 4$ in $\mathbf{2 a} \cdot \mathrm{H}_{2} \mathrm{O}$ and $\mathrm{Br} 1$ and $\mathrm{C} 7$ in 2d. Disorder of an ethyl piperazine-1carboxylate moiety in $\mathbf{2 c}$ was described by a split atom model using EADP constraints for respective atoms in the parts. Refinement of the ratio of occupancies by means of a free variable yielded 0.507(3):0.493(3). A Flack $x$ parameter of $0.016(18)$ for $2 \mathbf{c}$ was determined using 6035 quotients [(I+) $-(\mathrm{I}-)] /[(\mathrm{I}+)+(\mathrm{I}-)]$ (Parsons' method) [58]. The crystal of 2c studied was partially non-merohedrally twinned $\left[\begin{array}{lll}-1 & 0 & 0\end{array}\right.$

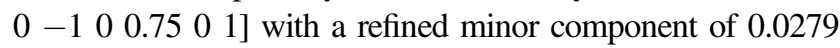
(6). In $\mathbf{2 a} \cdot \mathrm{H}_{2} \mathrm{O}$ and $\mathbf{2 b}$, hydrogen atom positions and $U_{\text {iso }}(\mathrm{H})$ values were refined freely. In $\mathbf{2 d}$, hydrogen atom positions were refined and $U_{\text {iso }}(\mathrm{H})$ values were set $1.2 U_{\text {eq }}(\mathrm{C})(1.5$ for methyl groups). In $\mathbf{2 c}$ and $\mathbf{2 e}$, hydrogen atoms were placed in geometrically calculated positions and refined using an appropriate riding model and $U_{\text {iso }}(\mathrm{H})=1.2 U_{\text {eq }}(\mathrm{C})(1.5$ for methyl groups). Torsion angles of methyl groups in $\mathbf{2 c}$ and $\mathbf{2 e}$ were initially determined via circular Fourier syntheses and subsequently refined while maintaining tetrahedral angles at the carbon atom. Structure pictures were drawn with Diamond [59] and Mercury [60].

\section{Crystal data for $2 \mathrm{a} \cdot \mathrm{H}_{2} \mathrm{O}$}

$\mathrm{C}_{15} \mathrm{H}_{18} \mathrm{FN}_{3} \mathrm{O}_{4} \mathrm{~S}, \quad M_{\mathrm{r}}=355.38, T=100(2) \mathrm{K}, \lambda=0.6199 \AA$, monoclinic, space group $P 2_{1} / c, a=10.659(2), b=21.099(4)$, $c=7.4526(15) \AA, \beta=107.77(3)^{\circ}, V=1596.2(6) \AA^{3}, Z=4$, $\rho_{\text {calc }}=1.479 \mathrm{mg} \mathrm{m}^{-3}, \mu=0.167 \mathrm{~mm}^{-1}, F(000)=744$, crystal size $0.136 \times 0.035 \times 0.013 \mathrm{~mm}, \theta$ range $1.68-27.00^{\circ}$, reflections collected/unique $33425 / 5016\left(R_{\text {int }}=0.0293\right), 292$ parameters, $S=1.071, R 1[I>2 \sigma(I)]=0.0249, \quad w R 2=0.0704$, $\Delta \rho_{\max } / \Delta \rho_{\min }=0.29 /-0.34 \mathrm{e}^{-3}$. 


\section{Crystal data for $2 b$}

$\mathrm{C}_{15} \mathrm{H}_{15} \mathrm{~F}_{2} \mathrm{~N}_{3} \mathrm{O}_{3} \mathrm{~S}, M_{\mathrm{r}}=355.36, T=100(2) \mathrm{K}, \lambda=0.6199 \AA$, triclinic, space group $P-1, a=10.305(2), b=12.616(3)$, $c=13.567(3) \AA, \alpha=112.19(3), \beta=102.29(3), \gamma=100.93$ (3) $)^{\circ}, V=1523.1(6) \AA^{3}, Z=4, \rho_{\text {calc }}=1.550 \mathrm{mg} \mathrm{m}^{-3}, \mu=$ $0.178 \mathrm{~mm}^{-1}, F(000)=736$, crystal size $0.087 \times 0.052 \times$ $0.043 \mathrm{~mm}, \theta$ range $1.49-27.00^{\circ}$, reflections collected/ unique $65202 / 10012 \quad\left(R_{\mathrm{int}}=0.0349\right), 556$ parameters, $S=1.034, \quad R 1 \quad[I>2 \sigma(I)]=0.0248, \quad w R 2=0.0682$, $\Delta \rho_{\max } / \Delta \rho_{\min }=0.40 /-0.36 \mathrm{e}^{-3}$.

\section{Crystal data for $2 c$}

$\mathrm{C}_{15} \mathrm{H}_{14} \mathrm{~F}_{3} \mathrm{~N}_{3} \mathrm{O}_{3} \mathrm{~S}, \quad M_{\mathrm{r}}=373.35, \quad T=150(2) \quad \mathrm{K}, \quad \lambda=$ $0.71073 \AA$, monoclinic, space group $C c, a=8.0599(3), b=$ 27.0465(11), $c=21.2617(8) \AA, \beta=98.159(2)^{\circ}, V=4588.0$ (3) $\AA^{3}, \quad Z=12, \quad \rho_{\text {calc }}=1.622 \mathrm{mg} \mathrm{m}^{-3}, \quad \mu=0.268 \mathrm{~mm}^{-1}$, $F(000)=2304$, crystal size $0.094 \times 0.035 \times 0.024 \mathrm{~mm}$, $\theta$ range $0.97-33.20^{\circ}$, reflections collected/unique $85259 /$ $17444\left(R_{\mathrm{int}}=0.0369\right), 712$ parameters, 2 restraints, $S=$ $1.052, R 1[I>2 \sigma(I)]=0.0484, w R 2=0.1319, \Delta \rho_{\max } / \Delta \rho_{\min }$ $=0.78 /-0.47 \mathrm{e}^{-3}$.

\section{Crystal data for $\mathbf{2 d}$}

$\mathrm{C}_{15} \mathrm{H}_{15} \mathrm{BrFN}_{3} \mathrm{O}_{3} \mathrm{~S}, M_{\mathrm{r}}=416.27, T=100(2) \mathrm{K} \lambda=1.54178 \AA$, monoclinic, space group $P 2{ }_{1} / c, a=8.3506(2), b=22.7598$ (5), $c=9.2142(2) \AA, \beta=110.481(1)^{\circ}, V=1640.53(6) \AA^{3}$, $Z=4, \rho_{\text {calc }}=1.685 \mathrm{mg} \mathrm{m}^{-3}, \mu=4.890 \mathrm{~mm}^{-1}, F(000)=840$, crystal size $0.150 \times 0.133 \times 0.051 \mathrm{~mm}, \theta$ range $=5.48-72.14^{\circ}$, reflections collected/unique $=25434 / 2970 \quad\left(R_{\text {int }}=0.0406\right)$, 265 parameters, $S=1.084, R 1[I>2 \sigma(I)]=0.0219, w R 2=$ $0.0527, \Delta \rho_{\max } / \Delta \rho_{\min }=0.42 /-0.50 \mathrm{e}^{-3}$.

\section{Crystal data for $2 e$}

$\mathrm{C}_{16} \mathrm{H}_{18} \mathrm{FN}_{3} \mathrm{O}_{4} \mathrm{~S}, M_{\mathrm{r}}=367.39, T=100(2) \mathrm{K}, \lambda=0.6199 \AA$, monoclinic, space group $P 2_{1} / c, a=10.525(2), b=21.450$ (4), $c=7.6170(15) \AA, \beta=109.53(3)^{\circ}, V=1620.7(6) \AA^{3}$, $Z=4, \quad \rho_{\text {calc }}=1.506 \mathrm{mg} \mathrm{m}^{-3}, \quad \mu=0.166 \mathrm{~mm}^{-1}, \quad F(000)=$ 768 , crystal size $0.084 \times 0.011 \times 0.005 \mathrm{~mm}, \quad \theta$ range 1.66-26.94 ${ }^{\circ}$, reflections collected/unique $32985 / 5208$ $\left(R_{\text {int }}=0.1033\right), 228$ parameters, $S=1.029, R 1[I>2 \sigma(I)]=$ $0.0649, w R 2=0.1878, \Delta \rho_{\max } / \Delta \rho_{\min }=0.87 /-0.38 \mathrm{e}^{-3}$.

\section{Microbiological assays}

The mycobacterial strains were routinely grown in $7 \mathrm{H} 9$ broth (Difco Middlebrook) supplemented with $10 \%$ (v/v) OADC (5\% bovine albumin fraction, $2 \%$ dextrose, 0.004 $\%$ catalase, $0.05 \%$ oleic acid and $0.8 \%$ sodium chloride solution) and $0.05 \%(\mathrm{v} / \mathrm{v})$ polysorbate 80 at $37{ }^{\circ} \mathrm{C}$ in standing cultures. Hygromycin B was added to the medium at a final concentration of $50 \mu \mathrm{g} \mathrm{mL}^{-1}$ for M. tuberculosis $\mathrm{H}_{37} \mathrm{Rv}$ pTEC27.

For the antimycobacterial activity assay against $M$. tuberculosis $\mathrm{H}_{37} \mathrm{Rv}$ (harbouring RFP expressing pTEC27 plasmid; the plasmid confers resistance to hygromycin), $\mathrm{MIC}_{90}$ values were determined by the broth microdilution method using flat-bottom 96-well Corning Costar plates. The highest concentration tested for each compound was $200 \mu \mathrm{g} \mathrm{mL}^{-1}$. Each well with the test compound and $7 \mathrm{H} 9$ medium supplemented with $10 \%$ OADC, $0.05 \%$ polysorbate 80 and hygromycin $\left(50 \mu \mathrm{g} \mathrm{mL}^{-1}\right)$ was then diluted twofold in a ten-point serial dilution. The concentration of the inoculum of $5 \times 10^{5}$ cells $\mathrm{mL}^{-1}\left(\mathrm{OD}_{600}, 0.1=0.33 \times 10^{8}\right.$ $\mathrm{CFU} \mathrm{mL} \mathrm{m}^{-1}$ ) was prepared from a starting inoculum that was diluted from a preculture at the mid-log phase $\left(\mathrm{OD}_{600}, 0.3\right.$ to 0.7). In each plate a negative control (1\% DMSO) and a positive control $\left(100 \mu \mathrm{g} \mathrm{mL}^{-1}\right.$ gentamicin) were included. Subsequently, $100 \mu \mathrm{L}$ of the bacterial inoculum were added to each well to give a final volume of $200 \mu \mathrm{L}$. The plates were then sealed with parafilm, placed in a container with moist tissue and incubated for six days at $37^{\circ} \mathrm{C}$. After incubation the fluorescence intensity of each well was measured with a BioTek Synergy H4 plate reader $\left(\lambda_{\mathrm{ex}}=\right.$ $530 \mathrm{~nm}, \lambda_{\mathrm{em}}=590 \mathrm{~nm}$ ) and the $\mathrm{MIC}_{90}$ value was calculated as the concentration of the compound that caused more than 90\% growth reduction. The determination was done in duplicate. The percentage of growth inhibition was calculated using the equation:

$$
\% \text { growth inhibition }=-100 \% \times \frac{\mathrm{OD}_{590}(\text { sample })-\mathrm{OD}_{590}(\mathrm{DMSO})}{\mathrm{OD}_{590}(\mathrm{DMSO})-\mathrm{OD}_{590}(\text { gentamicin })}
$$

Controls were used to monitor the assay quality through determination of the $Z^{\prime}$ score. The $Z^{\prime}$ factor was calculated as follows:

$Z^{\prime}=1-\frac{3\left(\mathrm{SD}_{\text {gentamicin }}+\mathrm{SD}_{\mathrm{DMSO}}\right)}{M_{\text {gentamicin }}-M_{\mathrm{DMSO}}}$

( $\mathrm{SD}=$ standard deviation, $\mathrm{M}=$ mean)

Against M. aurum DSM 43999, MIC values were determined using the broth microdilution method in 96-well flat-bottom tissue culture plates (Sarstedt, 83.3924.500), following a slightly modified literature procedure [61]. The test samples were dissolved in $10 \%$ DMSO at a concentration of $1 \mathrm{mg} \mathrm{mL}^{-1}$. In all the wells of a 96-well microtiter plate, $100 \mu \mathrm{L}$ of OADC supplemented Middlebrook broth were added followed by addition of $100 \mu \mathrm{L}$ of each sample in the first three wells. Broth and sample were mixed with the pipette and serially diluted down the wells. The highest concentration of the compounds tested was $250 \mu \mathrm{g} \mathrm{mL}^{-1}$. 
The positive controls used in this study were ciprofloxacin, isoniazid, rifampicin and triclosan at a concentration of $5 \mathrm{mg} \mathrm{mL}^{-1}$. Broth only, 10\% DMSO and M. aurum DSM 43999 only wells were used as the negative controls. M. aurum DSM 43999 suspension $(100 \mu \mathrm{L}$; adjusted to match McFarland standard 0.5 [62]) was added to all the wells, except the broth only wells and incubated for $72 \mathrm{~h}$ at $37^{\circ} \mathrm{C}$. INT from Sigma-Aldrich, Germany $(40 \mu \mathrm{L}, 0.2 \mathrm{mg}$ $\mathrm{mL}^{-1}$ ) was added to one column with the M. aurum DSM 43999 control and incubated for $30 \mathrm{~min}$ to one hour. When there was a colour change from clear to pink, the INT was added to all the wells and incubated for $30 \mathrm{~min}$ to $1 \mathrm{~h}$. The changing of the clear INT solution to a pink colour means that there is a bacterial growth in the well. Thus, the MIC is defined as the lowest concentration of sample where the colour of the INT remains still clear.

\section{Data availability}

NMR and MS spectra are depicted in the Supplementary Material. CCDC 2074617-2074621 contain the supplementary crystallographic data for this paper. These data can be obtained free of charge from the Cambridge Crystallographic Data Centre via www.ccdc.cam.ac.uk/ structures.

Acknowledgements Professor Christian W. Lehmann is gratefully acknowledged for providing access to the X-ray diffraction facilities. Thanks are due to Elke Dreher and Heike Schucht for technical assistance with the X-ray intensity data collections and Dr Christian Ihling, Antje Herbrich-Peters as well as Dirk Kampen for measuring the HRMS spectra. We would like to thank Professor Yossef Av-Gay, Sharlene Eivenmark and Stephanie Hughes for their support in planning and conducting the antimycobacterial testing. We acknowledge DESY (Hamburg, Germany), a member of the Helmholtz Association (HGF), for the provision of experimental facilities and we would like to thank Dr Sofiane Saouane for assistance in using the P11 beamline.

Funding BM received a grant within the TWAS-DFG Coorperation Visits Programme from the Deutsche Forschungsgemeinschaft and The World Academy of Sciences. Open Access funding enabled and organized by Projekt DEAL.

\section{Compliance with ethical standards}

Conflict of interest The authors declare no competing interests.

Consent for publication All authors have seen the manuscript and agree to its publication.

Publisher's note Springer Nature remains neutral with regard to jurisdictional claims in published maps and institutional affiliations.

Open Access This article is licensed under a Creative Commons Attribution 4.0 International License, which permits use, sharing, adaptation, distribution and reproduction in any medium or format, as long as you give appropriate credit to the original author(s) and the source, provide a link to the Creative Commons license, and indicate if changes were made. The images or other third party material in this article are included in the article's Creative Commons license, unless indicated otherwise in a credit line to the material. If material is not included in the article's Creative Commons license and your intended use is not permitted by statutory regulation or exceeds the permitted use, you will need to obtain permission directly from the copyright holder. To view a copy of this license, visit http://creativecommons. org/licenses/by/4.0/.

\section{References}

1. Global Tuberculosis Report 2020. Geneva: World Health Organization; 2020

2. Lange C, Chesov D, Heyckendorf J, Leung CC, Udwadia Z, Dheda K. Drug-resistant tuberculosis: An update on disease burden, diagnosis and treatment. Respirology. 2018;23:656-73. https://doi.org/10.1111/resp.13304

3. Koch A, Cox H, Mizrahi V. Drug-resistant tuberculosis: challenges and opportunities for diagnosis and treatment. Curr Opin Pharmacol. 2018;42:7-15. https://doi.org/10.1016/j.coph.2018.05.013

4. Lange C, Dheda K, Chesov D, Mandalakas AM, Udwadia Z, Horsburgh CR. Management of drug-resistant tuberculosis. Lancet. 2019;394:953-66. https://doi.org/10.1016/S0140-6736(19)31882-3

5. Cilloni L, Fu H, Vesga JF, Dowdy D, Pretorius C, Ahmedov S, et al. The potential impact of the COVID-19 pandemic on the tuberculosis epidemic a modelling analysis. EClinicalMedicine. 2020;28:100603 https://doi.org/10.1016/j.eclinm.2020.100603

6. Shetye GS, Franzblau SG, Cho S. New tuberculosis drug targets, their inhibitors, and potential therapeutic impact. Transl Res. 2020;220:68-97. https://doi.org/10.1016/j.trsl.2020.03.007

7. Makarov V, Manina G, Mikusova K, Möllmann U, Ryabova O, Saint-Joanis B, et al. Benzothiazinones kill Mycobacterium tuberculosis by blocking arabinan synthesis. Science. 2009;324:801-4. https://doi.org/10.1126/science.1171583

8. Makarov V, Mikušová K. Development of Macozinone for TB treatment: an update. Appl Sci. 2020;10:2269 https://doi.org/10. 3390/app10072269

9. Trefzer C, Škovierová H, Buroni S, Bobovská A, Nenci S, Molteni E, et al. Benzothiazinones are suicide inhibitors of mycobacterial decaprenylphosphoryl- $\beta$-d-ribofuranose 2 -oxidase DprE1. J Am Chem Soc. 2012;134:912-5. https://doi.org/10.1021/ja211042r

10. Chikhale RV, Barmade MA, Murumkar PR, Yadav MR. Overview of the development of DprE1 inhibitors for combating the menace of tuberculosis. J Med Chem. 2018;61:8563-93. https:// doi.org/10.1021/acs.jmedchem.8b00281

11. Mikusova K, Makarov V, Neres J. DprE1 - from the discovery to the promising tuberculosis drug target. Curr Pharm Des. 2014;20:4379-403. https://doi.org/10.2174/1381612820271406301 22724

12. Kannigadu C, N'Da DD. Recent advances in the synthesis and development of nitroaromatics as anti-infective drugs. Curr Pharm Des. 2020;26:4658-74. https://doi.org/10.2174/13816128266662 00331091853

13. Boelsterli UA, Ho HK, Zhou S, Leow KY. Bioactivation and hepatotoxicity of nitroaromatic drugs. Curr Drug Metab. 2006;7:715-27. https://doi.org/10.2174/138920006778520606

14. Purohit V, Basu AK. Mutagenicity of nitroaromatic compounds. Chem Res Toxicol. 2000;13:673-92. https://doi.org/10.1021/ tx000002x

15. Nepali K, Lee HY, Liou JP. Nitro-group-containing drugs. J Med Chem. 2019;62:2851-93. https://doi.org/10.1021/acs.jmedchem. $8 \mathrm{~b} 00147$

16. Makarov V, Neres J, Hartkoorn RC, Ryabova OB, Kazakova E, Šarkan M, et al. The 8-pyrrole-benzothiazinones are noncovalent inhibitors of DprE1 from Mycobacterium tuberculosis. 
Antimicrob Agents Chemother. 2015;59:4446-52. https://doi.org/ 10.1128/AAC.00778-15

17. Tiwari R, Miller PA, Chiarelli LR, Mori G, Šarkan M, Centárová I, et al. Design, syntheses, and anti-TB activity of 1,3-benzothiazinone azide and click chemistry products inspired by BTZ043. ACS Med Chem Lett. 2016;7:266-70. https://doi.org/ 10.1021/acsmedchemlett.5b00424

18. Zhang G, Chen D, Wang S, Chen H, Wei N, Chen G. Molecular insight into the discrepancy of antitubercular activity between 8nitro and 8-cyano benzothiazinones. ChemistrySelect. 2020;5: 13775-9. https://doi.org/10.1002/slct.202004156

19. Zhang G, Sheng L, Hegde P, Li Y, Aldrich CC. 8cyanobenzothiazinone analogs with potent antitubercular activity. Med Chem Res. 2021;30:449-58. https://doi.org/10.1007/ s00044-020-02676-4

20. Liu L, Kong C, Fumagalli M, Savková K, Xu Y, Huszár S, et al. Design, synthesis and evaluation of covalent inhibitors of DprE1 as antitubercular agents. Eur J Med Chem. 2020;208:112773 https://doi.org/10.1016/j.ejmech.2020.112773

21. Charushin VN, Nosova EV, Poteeva AD, Kotovskaya SK, Lipunova GN, Kravchenko MA, et al., inventors; FGBUN Institut Organicheskogo Sinteza im. I. Ya. Postovskogo Uralskogo Otdeleniya RAN, Russia; FGBU "Natsionalnyi Meditsinskii Issledovatelskii Tsentr Ftiziopulmonologii i Infektsionnykh Zabolevanii” Ministerstva Zdravookhr. Ross. Federatsii. assignee. Preparation of 5-fluoro-2-(4-ethoxycarbonylpiperazine-1-yl)-1,3benzothiazine-4-one with anti-tuberculosis activity patent RU2663848C1. 2018

22. Nosova EV, Batanova OA, Lipunova GN, Kotovskaya SK, Slepukhin PA, Kravchenko MA, et al. Synthesis and antitubercular evaluation of fluorinated 2-cycloalkylimino substituted 1,3-benzothiazin-4-ones. J Fluor Chem. 2019;220:69-77. https://doi.org/ 10.1016/j.jfluchem.2019.02.009

23. Phelan J, Maitra A, McNerney R, Nair M, Gupta A, Coll F, et al. The draft genome of Mycobacterium aurum, a potential model organism for investigating drugs against Mycobacterium tuberculosis and Mycobacterium leprae. Int J Mycobacteriology. 2015;4:207-16. https://doi.org/10.1016/j.ijmyco.2015.05.001

24. Madikizela B, McGaw LJ. Scientific rationale for traditional use of plants to treat tuberculosis in the eastern region of the OR Tambo district, South Africa. J Ethnopharmacol. 2018;224:250-60. https://doi.org/10.1016/j.jep.2018.06.002

25. Namouchi A, Cimino M, Favre-Rochex S, Charles P, Gicquel B. Phenotypic and genomic comparison of Mycobacterium aurum and surrogate model species to Mycobacterium tuberculosis: implications for drug discovery. BMC Genomics. 2017;18:530. https://doi.org/10.1186/s12864-017-3924-y

26. Nosova EV, Lipunova GN, Charushin VN, Chupakhin ON. Synthesis and biological activity of 2-amino- and 2-aryl (Heteryl) substituted 1,3-benzothiazin-4-ones. Mini Rev Med Chem. 2019;19:999-1014. https://doi.org/10.2174/1389557518666181015151801

27. Makarov VA, Cole ST, Moellmann U, inventors; Leibniz Institute for Natural Product Research and Infection Biology e.V. HansKnoell-Institut HKI, Germany. assignee. Preparation of piperidinylbenzothiazinones as antibacterials patent WO2007134625A1. 2007

28. Krygowski TM, Anulewicz R, Jarmula A, Ba̧k T, Rasala D, Howard $\mathrm{S}$. The effect of the methoxy group on the geometry of the benzene ring supported by crystal structure studies and $\mathrm{Ab}$ Initio Calculations. Crystal and molecular structure of 4-(4-methoxyphenyl)-2,6-diphenylpyridine and 1-methyl-4-(4-methoxy-phenyl)-2,6-diphenylpyridinium perchlorate. Tetrahedron. 1994;50:13155-64. https://doi.org/ 10.1016/S0040-4020(01)89325-X

29. Thakuria R, Sarma B, Nangia A. Hydrogen bonding in molecular crystals. In: Atwood JL, editor. Comprehensive Supramolecular Chemistry II. Oxford: Elsevier; 2017. p. 25-48
30. Kitajgorodskij AI. Molecular crystals and molecules. New York, NY: Academic Press; 1973

31. Steed KM, Steed JW. Packing problems: high $Z^{\prime}$ crystal structures and their relationship to cocrystals, inclusion compounds, and polymorphism. Chem Rev. 2015;115:2895-933. https://doi.org/ $10.1021 / \mathrm{cr} 500564 \mathrm{z}$

32. Bondi A. van der Waals volumes and radii. J Phys Chem. 1964;68:441-51. https://doi.org/10.1021/j100785a001

33. Neres J, Pojer F, Molteni E, Chiarelli LR, Dhar N, Boy-Röttger S, et al. Structural basis for benzothiazinone-mediated killing of Mycobacterium tuberculosis. Sci Transl Med. 2012;4:150ra21 https://doi.org/10.1126/scitranslmed.3004395

34. Richter A, Rudolph I, Möllmann U, Voigt K, Chung C-w, Singh OMP, et al. Novel insight into the reaction of nitro, nitroso and hydroxylamino benzothiazinones and of benzoxacinones with Mycobacterium tuberculosis DprE1. Sci Rep. 2018;8:13473. https://doi.org/10.1038/s41598-018-31316-6

35. Makarov V, Lechartier B, Zhang M, Neres J, van der Sar AM, Raadsen SA, et al. Towards a new combination therapy for tuberculosis with next generation benzothiazinones. EMBO Mol Med. 2014;6:372-83. https://doi.org/10.1002/emmm.201303575

36. Burley SK, Berman HM, Bhikadiya C, Bi C, Chen L, Di Costanzo L, et al. RCSB Protein Data Bank: biological macromolecular structures enabling research and education in fundamental biology, biomedicine, biotechnology and energy. Nucleic Acids Res. 2019;47:D464-D74. https://doi.org/10.1093/nar/gky1004

37. Groom CR, Bruno IJ, Lightfoot MP, Ward SC. The Cambridge Structural Database. Acta Crystallogr B Struct Sci Cryst Eng Mater. 2016;72:171-9. https://doi.org/10.1107/ S2052520616003954

38. Thomas IR, Bruno IJ, Cole JC, Macrae CF, Pidcock E, Wood PA. WebCSD: the online portal to the Cambridge Structural Database. J Appl Crystallogr. 2010;43:362-6. https://doi.org/10.1107/ s0021889810000452

39. Zhang G, Aldrich CC. Macozinone: revised synthesis and crystal structure of a promising new drug for treating drug-sensitive and drug-resistant tuberculosis. Acta Crystallogr Sect C. 2019;75:1031-5. https://doi.org/10.1107/S2053229619009185

40. Nosova EV, Poteeva AD, Lipunova GN, Slepukhin PA, Charushin VN. Synthesis of fluorine-containing 2-pyrrolyl- and 2indolyl-substituted 1,3-benzothiazin-4-ones. Russian J Org Chem. 2019;55:384-7. https://doi.org/10.1134/S1070428019030205

41. Baker RJ, Colavita PE, Murphy DM, Platts JA, Wallis JD. Fluorine-fluorine interactions in the solid state: an experimental and theoretical study. J Phys Chem A. 2012;116:1435-44. https:// doi.org/10.1021/jp2099976

42. Takaki K, Davis JM, Winglee K, Ramakrishnan L. Evaluation of the pathogenesis and treatment of Mycobacterium marinum infection in zebrafish. Nat Protoc. 2013;8:1114-24. https://doi. org/10.1038/nprot.2013.068

43. Cambier CJ, Takaki KK, Larson RP, Hernandez RE, Tobin DM, Urdahl KB, et al. Mycobacteria manipulate macrophage recruitment through coordinated use of membrane lipids. Nature. 2014;505:218-22. https://doi.org/10.1038/nature12799

44. Richter A, Strauch A, Chao J, Ko M, Av-Gay Y. Screening of preselected libraries targeting Mycobacterium abscessus for drug discovery. Antimicrob Agents Chemother. 2018;62:e00828-18. https://doi.org/10.1128/aac.00828-18

45. Ollinger J, Bailey MA, Moraski GC, Casey A, Florio S, Alling T, et al. A dual read-out assay to evaluate the potency of compounds active against Mycobacterium tuberculosis. PLOS ONE. 2013;8: e60531. https://doi.org/10.1371/journal.pone.0060531

46. Makarov V, Lechartier B, Zhang M, Neres J, van der Sar AM, Raadsen SA, et al. Towards a new combination therapy for tuberculosis with next generation benzothiazinones. EMBO Mol Med. 2014;6:372-83. https://doi.org/10.1002/emmm.201303575 
47. Trefzer C, Rengifo-Gonzalez M, Hinner MJ, Schneider P, Makarov V, Cole ST, et al. Benzothiazinones: prodrugs that covalently modify the decaprenylphosphoryl- $\beta$-d-ribose $2^{\prime}$-epimerase DprE1 of Mycobacterium tuberculosis. J Am Chem Soc. 2010;132:13663-5. https://doi.org/10.1021/ja106357w

48. Piton J, Foo CSY, Cole ST. Structural studies of Mycobacterium tuberculosis DprE1 interacting with its inhibitors. Drug Discov Today. 2017;22:526-33. https://doi.org/10.1016/j.drudis.2016.09.014

49. Meents A, Reime B, Stuebe N, Fischer P, Warmer M, Goeries D et al. Development of an in-vacuum x-ray microscope with cryogenic sample cooling for beamline P11 at PETRA III. Proc SPIE 2013;8851;88510K. https://doi.org/10.1117/12.2027303

50. Burkhardt A, Pakendorf T, Reime B, Meyer J, Fischer P, Stübe N, et al. Status of the crystallography beamlines at PETRA III. Eur Phys J. Plus 2016;131:1-9. https://doi.org/10.1140/epjp/i2016-16056-0

51. Kraft P, Bergamaschi A, Broennimann C, Dinapoli R, Eikenberry EF, Henrich B, et al. Performance of single-photon-counting PILATUS detector modules. J Synchrot Radiat. 2009;16:368-75. https://doi.org/10.1107/s0909049509009911

52. Kabsch W. XDS. Acta Crystallogr Sect D Biol Crystallogr. 2010;66:125-32. https://doi.org/10.1107/s0907444909047337

53. SAINT. Madison, Wisconsin, USA: Bruker AXS Inc.; 2012

54. SADABS. Madison, Wisconsin, USA: Bruker AXS Inc.; 2012

55. Sheldrick GM. SHELXT - integrated space-group and crystalstructure determination. Acta Crystallogr A Found Adv. 2015;71: 3-8. https://doi.org/10.1107/S2053273314026370
56. Sheldrick GM. Crystal structure refinement with SHELXL. Acta Crystallogr C Struct Chem. 2015;71:3-8. https://doi.org/10.1107/ S2053229614024218

57. Lübben J, Wandtke CM, Hübschle CB, Ruf M, Sheldrick GM, Dittrich B. Aspherical scattering factors for SHELXL - model, implementation and application. Acta Crystallogr A Found Adv. 2019;75:50-62. https://doi.org/10.1107/S2053273318013840

58. Parsons S, Flack HD, Wagner T. Use of intensity quotients and differences in absolute structure refinement. Acta Crystallogr B Struct Sci Cryst Eng Mater. 2013;69:249-59. https://doi.org/10. $1107 / \mathrm{S} 2052519213010014$

59. Brandenburg K. DIAMOND. 3.2k3 ed. Bonn, Germany: Crystal Impact GbR; 2018.

60. Macrae CF, Sovago I, Cottrell SJ, Galek PTA, McCabe P, Pidcock E, et al. Mercury 4.0: from visualization to analysis, design and prediction. J Appl Crystallogr. 2020;53:226-35. https://doi. org/10.1107/S1600576719014092

61. Mohammed MJ, Al-Bayati FA. Isolation and identification of antibacterial compounds from Thymus kotschyanus aerial parts and Dianthus caryophyllus flower buds. Phytomedicine. 2009;16:632-7. https://doi.org/10.1016/j.phymed. 2008.12.026

62. CLSI. Methods for Dilution Antimicrobial Susceptibility Tests for Bacteria That Grow Aerobically. 11th ed. CLSI standard M07. Wayne, Pennsylvania: Clinical and laboratory standards institute (CLSI); 2018 